удК 343.9

Д. В. Жкмуров

Байкальский государственный университет, г. Иркутск, Российская Федерация

\title{
КРИМИНАЛЬНАЯ МОТИВАЦИЯ
}

\begin{abstract}
АНнотАЦИя. В настоящей статье рассмотрены некоторые проблемные вопросы криминальной мотивации. Проанализированы ее дефиниции, изучены подходы и определения различных исследователей и проч. Автором предлагается ряд уточнений в существующую сегодня концепцию преступной мотивации. Во-первых, дано определение «мотива», исходя из наличия у него смыслообразующей функции, т.е. придания криминальной деятельности личностного значения. Во-вторых, предложен неклассический подход к пониманию полимотивированности преступной деятельности. Он предполагает существование «мотивационной пирамиды», т.е. многоуровневого психического образования, включающего первичные и вторичные формы мотивации преступного поведения. Предполагается, что криминальная активность обусловлена комплексом взаимосвязанных и взаимопорождающих мотивов. Кроме этого, разработана таблица основных видов потребностей и обусловленных ими криминальных мотивов с частными примерами. Она включает описание более тридцати форм криминальных мотивов.
\end{abstract}

кЛючЕВыЕ словА. Криминальная мотивация; криминальный мотив; мотивационная пирамида преступного поведения.

ИНФОРМАЦИЯ О СТАТЬЕ. Дата поступления 29 января 2018 г.; дата принятия к печати 19 марта 2018 г.; дата онлайн-размещения 09 апреля 2018 г.

D. V. Zhmurov

Baikal State University, Irkutsk, Russian Federation

\section{CRIMINAL MOTIVATION}

\begin{abstract}
This article considers some of the problematic issues of criminal motivation, analyses its definitions, studies the approaches and evaluations of various researchers, etc. The author offers a range of specifications to the current concept of criminal motivation. First, he gives a definition of the «motive» based on the presence of a meaning-forming function in it, i.e. giving personal significance to the criminal activity. Second, he offers a non-classical approach to understanding the poli-motivation of the criminal activity, which assumes the existence of a «motivational pyramid», i.e. multi-level mental education, which includes primary and secondary forms of motivation for criminal behaviour. The author proposes that the criminal activity is caused by a complex of interrelated and mutual motives. In addition, a table with specific examples is developed, which presents the main types of needs and criminal motives that they cause. It includes description of more than thirty forms of criminal motives. KEYWORDS. Criminal motivation; criminal motive; motivational pyramid of criminal behaviour.
\end{abstract}

ARTICLE INFO. Received January 29, 2018; accepted March 19, 2018; available online April 09, 2018.

«Мотив» и «мотивация» криминального поведения являются важнейшей частью преступной деятельности. И, хотя изучению этого явления уделяется немало внимания, ясности не становится больше. Проблемы во многом связаны с многозначностью данных понятий. Сегодня насчитывается более 50 гипотез, объясняющих природу мотивации [1]. Эти гипотезы, нередко, усложняют пони-

\section{Baikal Research Journal}


мание проблемы и дезориентируют исследователя. Отдельные ученые в этой связи высказывают мнение о нецелесообразности использования термина «мотив» [2].

Несмотря на вышесказанное, отечественная криминология придерживается гуманистических традиций и использует понятия «мотив» и «мотивация» при объяснении причин преступного поведения. Несомненно, эта область исследований является весьма дискуссионной. Укажем некоторые из наиболее спорных ее моментов.

Во-первых, как определять термин «преступный мотив»? Чаще всего под преступным мотивом понимается «побуждение» к противоправному поступку (Кудрявцев, Таранухин, Лунеев, Волков, Игошев, Иншаков и др.). Вместе с тем побуждение является достаточно неопределенным понятием, поскольку оно включает себя любые факторы, вызывающие активность, как внешние, так и внутренние. Побуждение не тождественно мотиву. Более того, побуждение не дает ответов на вопросы - почему, для чего, из-за чего индивид что-либо совершает? [3] Мотив, напротив, несет в себе смыслообразующую функцию, как бы объясняя причины деятельности, придавая ей личностное значение и понимание.

Во-вторых, как следует определять термин «мотивация преступного поведения»? Этот феномен также не получил однозначного толкования. В. Н. Кудрявцев определяет ее как «процесс формирования мотива преступления», В. В. Лунеев как «процесс возникновения, формирования и осуществления преступного поведения», включая в нее анализ совершенного деяния и раскаяние [4]. Анализируя указанные дефиниции, Е. П. Ильин высказывает мнение, что понимание «мотивации» в обоих случаях не лишено некоторых недостатков: у В. В. Лунеева «оно слишком расширено», а «у В. Н. Кудрявцева - заужено» [3].

В современных исследованиях предпринимаются и другие попытки дать определение «криминальной мотивации» [5]. По мнению Кирсановой О.С., это совокупность факторов, детерминирующих преступное поведение, включающих в себя «мотивы преступного поведения, склонность к отклоняющемуся поведению, эмоциональную мотивационную направленность и отрицательную нравственную ориентацию». В данном контексте мотивация объединяет в себе мотивы, склонности, нравственное мировоззрение и проч. Подобное определение еще раз подчеркивает нечеткость термина «мотивация», который, по-мнению Д. Дьюсбери, используется обычно как мусорная корзина для разного рода факторов, природа которых недостаточно ясна [6]. Следовательно, вопрос определения «мотивации» в большей степени зависит от личных предпочтений исследователя и его научных взглядов.

B-третьих, оправдано ли говорить о наличии криминальной мотивации без преступного деяния? Большинство криминологов дают отрицательный ответ на этот вопрос, поскольку факт совершения преступления является «отправной точкой» в поиске криминальной мотивации. Кудрявцев В. Н., к примеру, утверждает, что корыстный мотив, взятый вне преступления, не может рассматриваться как антисоциальный [7]. Психологи, напротив, считают этот довод ошибочным, указывая на некорректность отождествления преступного поведения и преступной мотивации. То, что человек не совершил преступление здесь и сейчас не обязательно означает, что у него нет криминальной мотивации. Реализация деяния могла быть отложена по каким-либо причинам. Индивид еще не преступник (и может им не стать), но уже социально опасен, поскольку имеет криминальную решимость [3]. Следовательно, предположение о том, что криминальная мотивация может существовать независимо от преступного деяния и задолго до него, выглядит не таким безосновательным.

B-четвертых, отличается ли криминальная мотивация от мотивации нормативного поведения? В работах по криминологии нередко можно встретить

\section{Baikal Research Journal}


утверждение о том, что криминальная и нормативная мотивация идентичны. С. В. Скляров предполагает, что «общие понятия мотивов преступного поведения и мотивов нормативного поведения не имеют принципиальных различий» [8]. Согласно В. В. Лунееву, В.Н. Кудрявцеву, мотивов, свойственных только преступному поведению, нет, как нет и антиобщественных потребностей и мотивов [3]. Эти высказывания, вероятно, справедливы, но только если рассматривать мотив, как побуждение к действию. Если же понимать его как основание и смысл поступка, то приходится отказываться от нейтральной природы мотивации. Подробные представления, как пишет Е.П. Ильин, возникли «у криминологов, потому, что мотив они понимают слишком узко, не включая в него как раз те элементы, которые делают поведение человека преступным: средство достижения цели, предвидение последствий, отношение к социальным ценностям» [3].

В-пятых, может ли исследователь выявить особенности криминальной мотивации, отталкиваясь от общепринятой сегодня классификации преступлений? По всей вероятности, традиционное деление преступлений на корыстные, насильственные и корыстно-насильственные, не всегда позволяет достоверно установить особенности мотивационной сферы лиц их совершивших. Так, нельзя исключать возможность того, что индивид может совершать «корыстные» преступления с агрессивной мотивацией. Например, уничтожение и повреждение чужого имущества по мотивам личной неприязни; кража из мести; присвоение и растрата с целью вредительства. Внешне указанные деяния, оставаясь, и будучи оценены правоприменителем, как корыстные, несут в себе явно агрессивное (враждебное) содержание. А понятие «насильственная кража» с т.з. психологической криминологии [9] вовсе не выглядит абсурдным. Несмотря на это, указанные преступники классифицируются как корыстные, не являясь таковыми по сути. Таким образом, отождествлять «характер деяния» и содержание криминальной мотивации следует не всегда. Она подлежит более углубленному изучению, при котором формальные критерии уголовных классификаций подходят не всегда.

Итак, поставленные выше вопросы в той или иной степени требуют разъяснения. Проблема «мотива» и «мотивации» преступного поведения ставит перед исследователем больше вопросов, чем ответов. Это связано со многими причинами, в числе которых отсутствие интереса к этой проблеме у многих криминологов, многозначность и запутанность терминологической базы, применение не всегда актуальных методических и теоретических разработок (напр., до сих пор используют выдающиеся труды Х. Хекхаузена 80-х гг., игнорируя при этом современные источники). Несмотря на наличие этих проблем, поставленная задача заключает в себе, по-мнению автора, значительный исследовательский потенциал.

В связи со сказанным, представляется уместным внести некоторые коррективы и дополнения в существующую концепцию криминальной мотивации. Перечислим их:

а) Целесообразно уточнить определение «мотива», исходя из наличия у него смыслообразующей функции, т.е. придания криминальной деятельности личностного значения. В этой связи мотив может пониматься как интегральное психическое образование, побуждающее к сознательныл асоциальныл действиял и придающее ил сльсловую определенность. Особо стоит подчеркнуть, что мотив - это не потребность ${ }^{1}$, не цель, не побуждение, поскольку ни одно из этих

1 Л. И. Божович, А. Н. Леонтьев утверждают, что потребность не может определить целенаправленное действие человека, а может вызвать лишь неорганизованную активность (исключая инстинктивные биологические потребности, которые связаны с врожденными механизмами их удовлетворения).

\section{Baikal Research Journal}

электронный научный журнал Байкальского государственного университета 
понятий не может полностью объяснить причину конкретного действия или поступка: почему нечто делается так, а не иначе.

Мотивация, в свою очередь, понимается как психический процесс форлирования мотивов. Этот процесс включает в себя актуализацию потребности, возникновение и формирование мотивов, целеобразование, выбор путей достижения цели, прогнозирование возможных результатов и принятие окончательного решения ${ }^{2}$.

Иллюстрация разнообразия мотивационной сферы преступника приведена в специально разработанной таблице негативных побуждений, обусловленных криминальной мотивацией (см. ниже табл. 1). В ходе анализа установлено, что для личности преступника характерны более 30 основных криминальных мотивов. Именно эти мотивы, комбинируясь под влиянием различных факторов, складываются во множество конфигураций криминальной мотивации.

Необходимо подчеркнуть, что изолированное изучение криминального мотива не дает исследователю полной картины происходящего. Сам по себе перечень мотивов весьма ограничен, а спектр конфигураций форм мотивации, напротив, не имеет определённого числа. Исходя из сказанного, представляется, что центр тяжести исследований современной криминологии должен быть смещен на «криминальную мотивацию», как явление более высокого порядка и большей сложности, нежели собственно мотив. Кудрявцев В. Н. также упоминает о данной проблеме, указывая на то, что нередко мотив рассматривается статически, без движения, изменения, преобразования. В работах юристов «ни о какой динамике мотивации» не упоминается, а принимается во внимание только один, действующий в определенный момент мотив [10, с. 5].

Итак, можно утверждать, что назрел вопрос о смене исследовательских приоритетов с «главенствующей роли мотива» в пользу доминирования «криминальной мотивации», как более сложного динамического явления. Это связано с тем, что все большее число криминологов разделяют позицию полимотивационности криминального поведения, т.е. возникновении его по нескольким взаимосвязанным мотивам.

б) Как упоминалось, гипотеза полимотивационности получила достаточное распространение в отечественной криминологии. Ю. М. Антонян, В. Е. Эминов отмечают, что человеку присуще богатство мотивационной среды, разнообразие и взаимодополняемость мотивов. Мотивы могут не только сотрудничать, но и усиливать, ослаблять друг друга, вступать во взаимные противоречия, следствием чего может быть правонарушение [11].

Кудрявцев В. Н. выделяет три формы полимотивации: 1) совокупность нескольких мотивов, побуждающих субъекта к действию (напр., кража по мотивам корысти и самоутверждения); 2) смена мотивов в процессе достижения цели (напр., убийство из мести, переходящее в корыстный акт); 3) конфликт или борьба мотивов [10].

Между тем в современной криминологии о полимотивации говорят скорее как об исключении, которое, безусловно, интересно с научной точки зрения, но не всегда является закономерностью преступного поведения. Упоминая о полимотивации, исследователи нередко оговариваются, что в психической сфере преступника все же существует ведущий мотив [8], остальные - являются вспомогательными. Для многих криминологов полимотивация - такое же естественное явление, как и мономотивация. Т.е. не исключается то, что некоторые преступления могут совершаться и с одним мотивом.

${ }^{2}$ Это определение, за некоторыми исключениями, дано в классической работе В. В. Лунеева. Преступное поведение: мотивация, прогнозирование, профилактика. М., 1980.

\section{Baikal Research Journal}

электронный научный журнал Байкальского государственного университета 
Однако если посмотреть на содержание «криминальной мотивации» под другим углом зрения, можно получить совершенное иные выводы, отрицающие всякую мономотивационную природу преступления.

Трудно согласиться с тем, что криминальный мотив возникает у преступника спонтанно, будто «на пустом месте». Представляется, что личность не может формировать асоциальные мотивы, не будучи «подготовленной» соответствующим образом. Индивид, до того как осознать необходимость преступления, должен, по крайней мере, быть «побужден» к: а) отрицанию правомерного поведения; б) поиску его возможных альтернатив; в) принятию норм криминальной активности. Криминальный мотив, каким его предпочитают изучать криминологи, сформирован на почве отрицания и неприятия социальных норм, а у этого процесса, безусловно, существуют какие-то свои мотивы. Здесь уместно обратиться к представлениям о первичной и вторичной природе любой мотивации.

Для пояснения сказанного целесообразно использовать понятие «мотивационной пирамиды». В данном исследовании она будет означать совокупность генетически взаилосвязанных первичных и вторичных мотивов преступного поведения.

Схематично «криминальная мотивация» может быть отражена в форме следующей мотивационной пирамиды (рис. 1):

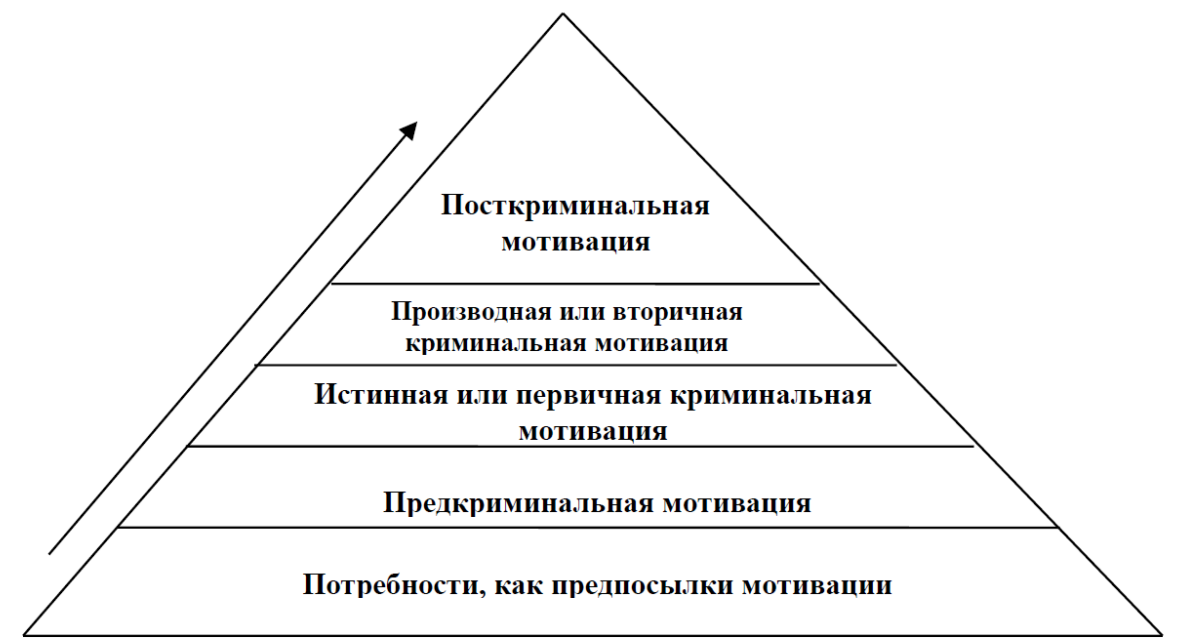

Рис. 1. Мотивационная пирамида криминального поведения

- Базовые и производные потребности отражены в приложении в табл. 1.

- Предкриминальная мотивация представляет собой совокупность психических конструктов, побуждающих индивида отказываться от просоциального поведения, искать ему замену, принимать образ поведения и социальную роль «преступника», искать способы удовлетворения потребностей вопреки социальным запретам и т.д. Данные мотивы не побуждают к совершению конкретного преступления, но создают идеальные предпосылки к формированию его первичной мотивации.

- Истинная или первичная криминальная мотивация - интегративное психическое образование, побуждающее к криминальному способу поведения. Это и есть «традиционный» комплекс мотивов преступления. Здесь уместно говорить о полимотивационности в том смысле, в котором она рассматривалась выше, т.е. обусловленности преступления несколькими мотивами. Появление истинной криминальной мотивации вторично по отношению к предкриминальной.

\section{Baikal Research Journal}


- Производная или вторичная криминальная мотивация характерна для закоренелых преступников. Она может быть выражена, во-первых, в «мотивационной установке», т.е. осознанном преступном намерении, которое является актуальным для личности и будет осуществлено при удобном случае; а во-вторых, в мотивационной схеме. Мотивационная схема понимается как поведенческий паттерн - тенденция к определенной форме поведения в конкретной ситуации, основанная на знаниях о возможных способах и средствах удовлетворения потребности [3]. Так, ставшая известной личности мотивация становится привычной и заносится в «мотивационный банк данных» с перспективной дальнейшего обращения к ней. Вполне возможно, что именно поэтому у многих рецидивистов не возникает вопроса о том, каким способом удовлетворять какую-либо потребность. При ее актуализации, они используют привычный мотивационный набор и совершают преступление.

- Посткриминальная мотивация заключается в формировании мотивов минимизации ответственности за собственные действия, мотивов дальнейшего соотнесения себя с социальной ролью девианта, мотивов самооправдания и т.д.

Весь этот «мотивационный комплекс» или «мотивационная пирамида» является психологической причиной преступного поведения. Полимотивность, таким образом, можно понимать в двух смыслах: а) классическом, когда речь идет о нескольких истинных мотивах, участвующих в генезе отдельного криминального акта; б) неклассическом, когда приходится признавать фракт полимотивности любого умышленного криминального действия. Эта полимотивность отражается в «мотивационной пирамиде», т.е. наборе мотивов различных уровней и содержания, каждый из которых играет генетически значимую роль в детерминации деликта.

в) Для современной криминологии актуальным и настоятельно требующим разрешения является вопрос о том, обладает ли «криминальная мотивация» автономной природой. По-мнению автора, ответ на него, скорее, должен быть положительным. Это связано с несколькими моментами.

Во-первых, криминальная мотивация - суть продукт криминализованного сознания, она существенно отличается от мотивации нормативного поведения хотя бы тем, что ставит перед индивидом преступные цели и позволяет их осознавать.

Во-вторых, не следует забывать о том, что криминальная мотивация может существовать в сознании индивида и без уголовно-наказуемого деяния в виде мотивационной схемы или установки. Безусловно, принятие подобной позиции не означает, что криминальную мотивацию с высокой степенью достоверности можно изучать не у преступников. Очевидно, что такие методики не всегда эффективны, хотя и необходимы.

Резюмируя вышесказанное, отметим некоторые существенные положения настоящей статьи:

Во-первых, мотив - это психическое образование, побуждающее к сознательным действиям и придающее им смысл. Сводить мотив к потребностям, целям или побуждениям не представляется целесообразным, поскольку ни одно из них не обнаруживает смыслообразующей функции.

Во-вторых, вероятно, существуют основания полагать, что любое умышленное преступление полимотивированно. Этот тезис раскрывается с помощью «мотивационной пирамиды», представляющей собой многоуровневое мотивационное образование, обусловливающее криминальное поведение. В связи с этим нельзя исключать возможность пересмотра существующих научных положений о полимотивности преступного поведения.

\section{Baikal Research Journal}

электронный научный журнал Байкальского государственного университета 
B-третьих, мотив не всегда должен играть ключевую роль в познании криминального поведения. Это объясняется его фрагментарной природой и включенностью, прежде всего, в криминальную мотивацию, которой принадлежит приоритетное значение в формировании индивидуального преступного поведения. Последняя обладает относительной самостоятельностью, более того, как было установлено выше, она не соотносится с мотивацией нормативного поведения. Поэтому криминальная мотивация должна изучаться исключительно в рамках криминологии и криминальной психологии.

Таблица 1. Основные виды потребностей, их внешнее выражение, проявление в связи с ними криминального мотива и частные примеры обусловленной ими деятельности.

Данная классификация потребностей разработана:

1) John E. Barbulo, Richard W. Scholl. Motivation Sources Inventory: Development and Validation of New Scales to Measure an Infegrative Taxonomy of Motivation. Psychological Reports, 1998, 82, 1011-1022;

2) Проявления криминальных мотивов с частными примерами (Д. В. Жмуров).

\begin{tabular}{|c|c|c|c|}
\hline $\begin{array}{c}\text { Первичные } \\
\text { или биологические } \\
\text { потребности }\end{array}$ & $\begin{array}{c}\text { Внешнее выраже- } \\
\text { ние потребности }\end{array}$ & $\begin{array}{c}\text { Проявление } \\
\text { криминального мотива }\end{array}$ & $\begin{array}{c}\text { Частный пример } \\
\text { внешнего проявления }\end{array}$ \\
\hline $\begin{array}{l}\text { 1. Потребность } \\
\text { в кислороде }\end{array}$ & & - & $\begin{array}{l}\text { Рефлекторная актив- } \\
\text { ность }\end{array}$ \\
\hline $\begin{array}{l}\text { 2. Потребность } \\
\text { в мочеиспускании }\end{array}$ & & - & $\begin{array}{l}\text { Рефлекторная актив- } \\
\text { ность }\end{array}$ \\
\hline $\begin{array}{l}\text { 3. Потребность } \\
\text { в дефекации }\end{array}$ & & - & $\begin{array}{l}\text { Рефлекторная актив- } \\
\text { ность }\end{array}$ \\
\hline $\begin{array}{l}\text { 4. Потребность } \\
\text { в лактации }\end{array}$ & & - & $\begin{array}{l}\text { Рефлекторная актив- } \\
\text { ность }\end{array}$ \\
\hline $\begin{array}{l}\text { 5. Потребность } \\
\text { в воде }\end{array}$ & Потреблять пище- & $\begin{array}{l}\text { Побуждение к удовлетворе- } \\
\text { нию пищевых потребностей }\end{array}$ & Воровство пищевых \\
\hline $\begin{array}{l}\text { 6. Потребность } \\
\text { в пище }\end{array}$ & вые продукты & криминальным способом & продуктов \\
\hline $\begin{array}{l}\text { 7. Сексуальная } \\
\text { потребность }\end{array}$ & $\begin{array}{l}\text { Вступать в поло- } \\
\text { вые сношения }\end{array}$ & $\begin{array}{l}\text { Побуждение к удовлетво- } \\
\text { рению сексуальной по- } \\
\text { требности криминальным } \\
\text { способом }\end{array}$ & $\begin{array}{l}\text { Совершение изнасило- } \\
\text { вания }\end{array}$ \\
\hline $\begin{array}{l}\text { 8. Потребность } \\
\text { в избегании } \\
\text { повреждений }\end{array}$ & \multirow{4}{*}{$\begin{array}{l}\text { Обладать личной } \\
\text { неприкосновенно- } \\
\text { стью, простран- } \\
\text { ством, относи- } \\
\text { тельной свободой } \\
\text { деятельности }\end{array}$} & \multirow{4}{*}{$\begin{array}{l}\text { Побуждение к удовлетворе- } \\
\text { нию потребности в безо- } \\
\text { пасности криминальным } \\
\text { способом }\end{array}$} & \multirow{4}{*}{$\begin{array}{l}\text { Совершение кри- } \\
\text { минальных актов с } \\
\text { целью реальной или } \\
\text { мнимой самозащи- } \\
\text { ты, пресечения угроз } \\
\text { личной безопасности, } \\
\text { превентивное крими- } \\
\text { нальное поведение } \\
\text { (напр., убийство в } \\
\text { ходе самообороны). }\end{array}$} \\
\hline $\begin{array}{l}\text { 9. Потребность } \\
\text { в избегании отрав- } \\
\text { ления }\end{array}$ & & & \\
\hline $\begin{array}{l}\text { 10. Потребность } \\
\text { в избегании пере- } \\
\text { гревания }\end{array}$ & & & \\
\hline $\begin{array}{l}\text { 11. Потребность } \\
\text { в избегании пере- } \\
\text { охлаждения }\end{array}$ & & & \\
\hline $\begin{array}{l}\text { 12. Потребность } \\
\text { в ощущениях }\end{array}$ & $\begin{array}{l}\text { Получать аффек- } \\
\text { тивные пережи- } \\
\text { вания }\end{array}$ & $\begin{array}{l}\text { Побуждение к удовлет- } \\
\text { ворению потребности в } \\
\text { ощущениях криминальным } \\
\text { способом }\end{array}$ & $\begin{array}{l}\text { Совершение хулиган- } \\
\text { ства, грабежа, угона } \\
\text { автомобиля, изнасило- } \\
\text { вания и т.д. с целью } \\
\text { испытать аффектив- } \\
\text { ную разрядку и эмо- } \\
\text { циональное волнение }\end{array}$ \\
\hline
\end{tabular}

\section{Baikal Research Journal}


Продолжение табл.

\begin{tabular}{|c|c|c|c|}
\hline $\begin{array}{c}\text { Первичные } \\
\text { или биологические } \\
\text { потребности }\end{array}$ & $\begin{array}{c}\text { Внешнее выраже- } \\
\text { ние потребности }\end{array}$ & $\begin{array}{c}\text { Проявление } \\
\text { криминального мотива }\end{array}$ & $\begin{array}{c}\text { Частный пример } \\
\text { внешнего проявления }\end{array}$ \\
\hline \multicolumn{4}{|c|}{ Вторичные или психогенные потребности } \\
\hline $\begin{array}{l}\text { 14. Потребность } \\
\text { приобретения }\end{array}$ & $\begin{array}{l}\text { Добывать имуще- } \\
\text { ство и собствен- } \\
\text { ность }\end{array}$ & $\begin{array}{l}\text { Побуждение к удовлетво- } \\
\text { рению потребности при- } \\
\text { обретения криминальным } \\
\text { способом }\end{array}$ & $\begin{array}{l}\text { Совершение кражи, } \\
\text { грабежа, разбоя, эко- } \\
\text { номических престу- } \\
\text { плений и т.д. }\end{array}$ \\
\hline $\begin{array}{l}\text { 15. Потребность } \\
\text { охраны }\end{array}$ & $\begin{array}{l}\text { Чинить, чистить } \\
\text { и охранять вещи; } \\
\text { защищать их от } \\
\text { повреждения }\end{array}$ & $\begin{array}{l}\text { Побуждение к удовлетво- } \\
\text { рению потребности охраны } \\
\text { криминальным способом }\end{array}$ & $\begin{array}{l}\text { Криминальное на- } \\
\text { силие в отношении } \\
\text { лица, покусившегося } \\
\text { на принадлежащую } \\
\text { вещь (нанесение те- } \\
\text { лесных повреждений } \\
\text { виновной стороне по- } \\
\text { вредившей автомобиль } \\
\text { в ДТП) }\end{array}$ \\
\hline $\begin{array}{l}\text { 16. Потребность } \\
\text { порядка }\end{array}$ & $\begin{array}{l}\text { Устраивать, си- } \\
\text { стематизировать, } \\
\text { складывать вещи. } \\
\text { Быть опрятным } \\
\text { и чистым. Быть } \\
\text { скрупулезно } \\
\text { точным }\end{array}$ & $\begin{array}{l}\text { Побуждение к удовлетворе- } \\
\text { нию потребности порядка } \\
\text { криминальным способом }\end{array}$ & $\begin{array}{l}\text { Силовое принужде- } \\
\text { ние низшей касты } \\
\text { заключенных к под- } \\
\text { держанию порядка в } \\
\text { определенных местах } \\
\text { ИУ, считающихся } \\
\text { «нечистыми» }\end{array}$ \\
\hline $\begin{array}{l}\text { 17. Потребность } \\
\text { удержания }\end{array}$ & $\begin{array}{l}\text { Сохранять вла- } \\
\text { дение чем-либо. } \\
\text { Делать запасы. }\end{array}$ & $\begin{array}{l}\text { Побуждение к удовлетво- } \\
\text { рению потребности удер- } \\
\text { жания криминальным } \\
\text { способом }\end{array}$ & $\begin{array}{l}\text { Уклонение от уплаты } \\
\text { налогов; алиментов, } \\
\text { таможенных сборов и } \\
\text { пошлин и проч. }\end{array}$ \\
\hline $\begin{array}{l}\text { 18. Потребность } \\
\text { конструирования }\end{array}$ & $\begin{array}{l}\text { Организовывать и } \\
\text { строить }\end{array}$ & $\begin{array}{l}\text { Побуждение к удовлетворе- } \\
\text { нию потребности констру- } \\
\text { ирования криминальным } \\
\text { способом }\end{array}$ & $\begin{array}{l}\text { Незаконное изготовле- } \\
\text { ние оружия, наркоти- } \\
\text { ческих средств, под- } \\
\text { дельных документов, } \\
\text { денег, ценных бумаг } \\
\text { и проч. }\end{array}$ \\
\hline $\begin{array}{l}\text { 19. Потребность } \\
\text { превосходства }\end{array}$ & \multicolumn{3}{|c|}{ Подразделяется на две потребности: } \\
\hline $\begin{array}{l}\text { Потребность } \\
\text { достижения }\end{array}$ & $\begin{array}{l}\text { Преодолевать } \\
\text { препятствия, } \\
\text { развивать силы, } \\
\text { стараться сделать } \\
\text { что-то трудное } \\
\text { как можно лучше } \\
\text { и быстрее }\end{array}$ & \multirow{2}{*}{$\begin{array}{l}\text { Побуждение к удовлетворе- } \\
\text { нию потребности достиже- } \\
\text { ния и признания крими- } \\
\text { нальным способом }\end{array}$} & $\begin{array}{l}\text { Стремление к совер- } \\
\text { шению преступлений с } \\
\text { высоким уровнем кри- } \\
\text { минального професси- } \\
\text { онализма (оттачивание } \\
\text { преступного ремесла) }\end{array}$ \\
\hline $\begin{array}{l}\text { Потребность } \\
\text { признания }\end{array}$ & $\begin{array}{l}\text { Усилия завоевать } \\
\text { одобрение и высо- } \\
\text { кий социальный } \\
\text { статус. Завоевы- } \\
\text { вать похвалу и } \\
\text { одобрение }\end{array}$ & & $\begin{array}{l}\text { Совершение кражи } \\
\text { подростками, неко- } \\
\text { торые из которых } \\
\text { действуют с целью } \\
\text { группового одобрения }\end{array}$ \\
\hline $\begin{array}{l}\text { 20. Потребность } \\
\text { демонстрирования }\end{array}$ & $\begin{array}{l}\text { Привлекать } \\
\text { внимание. Воз- } \\
\text { буждать, развле- } \\
\text { кать, шокировать, } \\
\text { волновать других. } \\
\text { Самодраматизация }\end{array}$ & $\begin{array}{l}\text { Побуждение к удовлетворе- } \\
\text { нию истерических потреб- } \\
\text { ностей криминальным } \\
\text { способом }\end{array}$ & $\begin{array}{l}\text { Провокационное по- } \\
\text { ведение, инициация } \\
\text { драк, хулиганство, } \\
\text { публичные призывы } \\
\text { к насилию, угрозы } \\
\text { убийством и проч. }\end{array}$ \\
\hline
\end{tabular}

\section{Baikal Research Journal}


Продолжение табл.

\begin{tabular}{|c|c|c|c|}
\hline $\begin{array}{c}\text { Первичные } \\
\text { или биологические } \\
\text { потребности }\end{array}$ & $\begin{array}{c}\text { Внешнее выраже- } \\
\text { ние потребности }\end{array}$ & $\begin{array}{c}\text { Проявление } \\
\text { криминального мотива }\end{array}$ & $\begin{array}{c}\text { Частный пример } \\
\text { внешнего проявления }\end{array}$ \\
\hline $\begin{array}{l}\text { 21. Потребность не- } \\
\text { прикосновенности }\end{array}$ & \multicolumn{3}{|c|}{ Подразделяется на три потребности: } \\
\hline $\begin{array}{l}\text { Потребность избе- } \\
\text { жания бесчестья }\end{array}$ & $\begin{array}{l}\text { Избегать неудач, } \\
\text { стыда, унижения, } \\
\text { насмешек }\end{array}$ & \multirow{3}{*}{$\begin{array}{l}\text { Побуждение к удовлет- } \\
\text { ворению потребности в } \\
\text { безопасности криминаль- } \\
\text { ным способом }\end{array}$} & \multirow{3}{*}{$\begin{array}{l}\text { Преступления, совер- } \\
\text { шаемые в контексте } \\
\text { «культуры чести» } \\
\text { (напр., криминальной, } \\
\text { «пацанской» субкуль- } \\
\text { тур), а также из мести, } \\
\text { мнимой или реальной } \\
\text { самообороны }\end{array}$} \\
\hline $\begin{array}{l}\text { Потребность за- } \\
\text { щиты }\end{array}$ & $\begin{array}{l}\text { Защищать себя от } \\
\text { стыда и приниже- } \\
\text { ния. Оправдывать } \\
\text { чьи-то действия. } \\
\text { Предлагать объяс- } \\
\text { нения, извинения } \\
\text { и оправдания }\end{array}$ & & \\
\hline $\begin{array}{l}\text { Потребность про- } \\
\text { тиводействия }\end{array}$ & \begin{tabular}{|l|} 
Преодолевать \\
неудачи. Дока- \\
зать собственную \\
значимость. Ото- \\
мстить за оскор- \\
бление. Защищать \\
честь с помощью \\
действия
\end{tabular} & & \\
\hline $\begin{array}{l}\text { 22. Потребность } \\
\text { доминирования }\end{array}$ & $\begin{array}{l}\text { Влиять на других } \\
\text { или контролиро- } \\
\text { вать их. Убеж- } \\
\text { дать, запрещать, } \\
\text { диктовать }\end{array}$ & $\begin{array}{l}\text { Побуждение к удовлет- } \\
\text { ворению потребности в } \\
\text { доминирования крими- } \\
\text { нальным способом }\end{array}$ & $\begin{array}{l}\text { Совершение преступле- } \\
\text { ний с целью ощутить } \\
\text { власть над жертвой } \\
\text { (истязания, жестокое } \\
\text { обращение с детьми и } \\
\text { животными и проч.) }\end{array}$ \\
\hline $\begin{array}{l}\text { 23. Потребность } \\
\text { почитания }\end{array}$ & $\begin{array}{l}\text { Восхищаться } \\
\text { превосходящим } \\
\text { и добровольно } \\
\text { следовать за ним. } \\
\text { Сотрудничать с } \\
\text { лидером. Радост- } \\
\text { но служить } \\
\end{array}$ & $\begin{array}{l}\text { Побуждение к удовлет- } \\
\text { ворению потребности по- } \\
\text { читания криминальным } \\
\text { способом }\end{array}$ & $\begin{array}{l}\text { Преступления, совер- } \\
\text { шенные под влиянием } \\
\text { лидера, авторитета, } \\
\text { провокатора }\end{array}$ \\
\hline $\begin{array}{l}\text { 24. Потребность } \\
\text { уподобления }\end{array}$ & $\begin{array}{l}\text { Имитировать. } \\
\text { Идентифици- } \\
\text { ровать себя с } \\
\text { остальными. } \\
\text { Соглашаться и } \\
\text { верить }\end{array}$ & $\begin{array}{l}\text { Побуждение к удовлетво- } \\
\text { рению потребности упо- } \\
\text { добления криминальным } \\
\text { способом }\end{array}$ & $\begin{array}{l}\text { Преступления-ими- } \\
\text { тации (подробно см. } \\
\text { Жмуров Д.В. Сценарная } \\
\text { агрессия несовершенно- } \\
\text { летних) }\end{array}$ \\
\hline $\begin{array}{l}25 . \text { Потребность } \\
\text { автономии }\end{array}$ & $\begin{array}{l}\text { Сопротивляться } \\
\text { влиянию и наси- } \\
\text { лию. Не повино- } \\
\text { ваться власти или } \\
\text { искать свободы } \\
\text { на новом месте. } \\
\text { Бороться за неза- } \\
\text { висимость }\end{array}$ & $\begin{array}{l}\text { Побуждение к удовлет- } \\
\text { ворению потребности ав- } \\
\text { тономии криминальным } \\
\text { способом }\end{array}$ & $\begin{array}{l}\text { Массовое неповинове- } \\
\text { ние в местах лишения } \\
\text { свободы, неисполнение } \\
\text { приказа или распоряже- } \\
\text { ния и проч. }\end{array}$ \\
\hline $\begin{array}{l}\text { 26. Потребность } \\
\text { противоречия }\end{array}$ & $\begin{array}{l}\text { Действовать не } \\
\text { так, как другие. } \\
\text { Быть единствен- } \\
\text { ным в своем роде }\end{array}$ & $\begin{array}{l}\text { Побуждение к удовлет- } \\
\text { ворению потребности в } \\
\text { противоречии криминаль- } \\
\text { ным способом }\end{array}$ & $\begin{array}{l}\text { Вандализм, хулиган- } \\
\text { ство, уничтожение } \\
\text { памятников культуры } \\
\text { и проч. }\end{array}$ \\
\hline
\end{tabular}

\section{Baikal Research Journal}


Продолжение табл.

\begin{tabular}{|c|c|c|c|}
\hline $\begin{array}{c}\text { Первичные } \\
\text { или биологические } \\
\text { потребности }\end{array}$ & $\begin{array}{c}\text { Внешнее выраже- } \\
\text { ние потребности }\end{array}$ & $\begin{array}{c}\text { Проявление } \\
\text { криминального мотива }\end{array}$ & $\begin{array}{c}\text { Частный пример } \\
\text { внешнего проявления }\end{array}$ \\
\hline $\begin{array}{l}\text { 27. Потребность } \\
\text { агрессии }\end{array}$ & $\begin{array}{l}\text { Напасть на объ- } \\
\text { ект или повре- } \\
\text { дить его. Убить. } \\
\text { Принижать, вре- } \\
\text { дить, обвинять, } \\
\text { стыдить или злоб- } \\
\text { но высмеивать } \\
\text { человека }\end{array}$ & $\begin{array}{l}\text { Побуждение к удовлет- } \\
\text { ворению потребности } \\
\text { агрессии криминальным } \\
\text { способом }\end{array}$ & $\begin{array}{l}\text { Преступления, со- } \\
\text { вершенные с особой } \\
\text { жестокостью, с причи- } \\
\text { нением жертве особых } \\
\text { страданий (убийство, } \\
\text { изнасилование, теле- } \\
\text { сные повреждения) }\end{array}$ \\
\hline $\begin{array}{l}\text { 28. Потребность в } \\
\text { уничижении }\end{array}$ & $\begin{array}{l}\text { Капитулировать. } \\
\text { Уступить и под- } \\
\text { вергнуться нака- } \\
\text { занию. Извинять- } \\
\text { ся, признавать } \\
\text { вину, искупать } \\
\text { вину }\end{array}$ & $\begin{array}{l}\text { Побуждение к удовлет- } \\
\text { ворению потребности в } \\
\text { уничижении криминаль- } \\
\text { ным способом }\end{array}$ & $\begin{array}{l}\text { Заглаживание вины пе- } \\
\text { ред значимыми лицами } \\
\text { посредством совершения } \\
\text { преступления. Встреча- } \\
\text { ются интересные при- } \\
\text { меры в мусульманской } \\
\text { религиозной традиции. } \\
\text { «Черные аисты» (Чо- } \\
\text { хатлор) - это те люди, } \\
\text { которые совершили } \\
\text { преступление перед Ал- } \\
\text { лахом: убили, украли и } \\
\text { прочее. Искупить свою } \\
\text { вину перед Аллахом } \\
\text { они должны были толь- } \\
\text { ко кровью неверных }\end{array}$ \\
\hline $\begin{array}{l}\text { 29. Потребность } \\
\text { избегания вины }\end{array}$ & $\begin{array}{l}\text { Избегать вины, } \\
\text { остракизма или } \\
\text { наказания при } \\
\text { помощи подавле- } \\
\text { ния асоциальных } \\
\text { или неприятных } \\
\text { импульсов }\end{array}$ & $\begin{array}{l}\text { Побуждение к удовлет- } \\
\text { ворению потребности } \\
\text { избегания вины крими- } \\
\text { нальным способом }\end{array}$ & $\begin{array}{l}\text { Любые криминальные } \\
\text { способы избегания на- } \\
\text { казания, напр. убийство } \\
\text { с целью скрыть другое } \\
\text { преступление }\end{array}$ \\
\hline $\begin{array}{l}\text { 30. Потребность } \\
\text { присоединения } \\
\text { (аффилиации) }\end{array}$ & $\begin{array}{l}\text { Устанавливать } \\
\text { дружеские отно- } \\
\text { шения и связи. } \\
\text { Приветствовать, } \\
\text { присоединяться, } \\
\text { жить вместе с } \\
\text { другими. Сотруд- } \\
\text { ничать и общать- } \\
\text { ся с другими }\end{array}$ & $\begin{array}{l}\text { Побуждение к удовлетво- } \\
\text { рению потребности аффи- } \\
\text { лиации криминальным } \\
\text { способом }\end{array}$ & $\begin{array}{l}\text { Участие в группиров- } \\
\text { ках, организациях } \\
\text { криминальной направ- } \\
\text { ленности с целью ощу- } \\
\text { щения сопричастности, } \\
\text { дружности, единства и } \\
\text { т.д. }\end{array}$ \\
\hline $\begin{array}{l}\text { 31. Потребность } \\
\text { отвержения }\end{array}$ & $\begin{array}{l}\text { Презирать, иг- } \\
\text { норировать или } \\
\text { исключать объ- } \\
\text { екты. Оставаться } \\
\text { безразличным, } \\
\text { быть в стороне }\end{array}$ & $\begin{array}{l}\text { Побуждение к удовлетво- } \\
\text { рению потребности отвер- } \\
\text { жения криминальным } \\
\text { способом }\end{array}$ & $\begin{array}{l}\text { Криминальный остра- } \\
\text { кизм в исправительных } \\
\text { учреждениях, насиль- } \\
\text { ственные действия с } \\
\text { кастой «обиженных». }\end{array}$ \\
\hline $\begin{array}{l}\text { 32. Потребность } \\
\text { покровительства }\end{array}$ & $\begin{array}{l}\text { Относиться с сим- } \\
\text { патией, помогать } \\
\text { беспомощному } \\
\text { или защищать } \\
\text { его. Выражать } \\
\text { симпатию }\end{array}$ & $\begin{array}{l}\text { Побуждение к удовлет- } \\
\text { ворению потребности } \\
\text { покровительства крими- } \\
\text { нальным способом }\end{array}$ & $\begin{array}{l}\text { Организация преступ- } \\
\text { ной группы, группы, } \\
\text { незаконного вооружен- } \\
\text { ного формирования; } \\
\text { заранее обещанное } \\
\text { пособничество и проч. }\end{array}$ \\
\hline
\end{tabular}

\section{Baikal Research Journal}


Окончание табл.

\begin{tabular}{|c|c|c|c|}
\hline $\begin{array}{c}\text { Первичные } \\
\text { или биологические } \\
\text { потребности }\end{array}$ & $\begin{array}{c}\text { Внешнее выраже- } \\
\text { ние потребности }\end{array}$ & $\begin{array}{c}\text { Проявление } \\
\text { криминального мотива }\end{array}$ & $\begin{array}{c}\text { Частный пример } \\
\text { внешнего проявления }\end{array}$ \\
\hline $\begin{array}{l}\text { 33. Потребность в } \\
\text { поддержке }\end{array}$ & $\begin{array}{l}\text { Искать помоши, } \\
\text { защиты или сим- } \\
\text { патии. Молить о } \\
\text { помощи }\end{array}$ & $\begin{array}{l}\text { Побуждение к удовлет- } \\
\text { ворению потребности в } \\
\text { поддержке криминаль- } \\
\text { ным способом }\end{array}$ & $\begin{array}{l}\text { Присоединение к пре- } \\
\text { ступной группировке } \\
\text { и совершение престу- } \\
\text { плений, в т.ч. с целью } \\
\text { получить криминаль- } \\
\text { ную защиту остальных } \\
\text { ее членов }\end{array}$ \\
\hline $\begin{array}{l}\text { 34. Потребность } \\
\text { игры }\end{array}$ & $\begin{array}{l}\text { Расслабляться, } \\
\text { развлекать себя, } \\
\text { искать разноо- } \\
\text { бразия и удоволь- } \\
\text { ствий. Веселить- } \\
\text { ся, играть в игры. } \\
\text { Смеяться, шутить }\end{array}$ & $\begin{array}{l}\text { Побуждение к удовлет- } \\
\text { ворению игровой потреб- } \\
\text { ности криминальным } \\
\text { способом }\end{array}$ & $\begin{array}{l}\text { Совершение магазин- } \\
\text { ных и карманных краж } \\
\text { с высокой степенью } \\
\text { риска быть пойман- } \\
\text { ным; мошенничество, в } \\
\text { котором «осуществля- } \\
\text { ется интеллектуальное } \\
\text { противоборство, состя- } \\
\text { зание в ловкости, сооб- } \\
\text { разительности, умении } \\
\text { максимально исполь- } \\
\text { зовать благоприятные } \\
\text { обстоятельства и быстро } \\
\text { принимать решения» } \\
\text { [12 с. 80-89] }\end{array}$ \\
\hline $\begin{array}{l}\text { 35. Потребность } \\
\text { познания }\end{array}$ & $\begin{array}{l}\text { Исследовать, дви- } \\
\text { гаясь и касаясь. } \\
\text { Задавать вопросы. } \\
\text { Удовлетворять } \\
\text { любопытство. } \\
\text { Смотреть, слу- } \\
\text { шать, проверять }\end{array}$ & $\begin{array}{l}\text { Побуждение к удовлет- } \\
\text { ворению познавательной } \\
\text { потребности криминаль- } \\
\text { ным способом }\end{array}$ & $\begin{array}{l}\text { Напр., совершение } \\
\text { некоторых ритуальных } \\
\text { насильственных престу- } \\
\text { плений с целью при- } \\
\text { общится к «высшему } \\
\text { знанию» }\end{array}$ \\
\hline $\begin{array}{l}\text { 36. Потребность } \\
\text { высказывания }\end{array}$ & $\begin{array}{l}\text { Указывать и } \\
\text { демонстрировать. } \\
\text { Пересказывать } \\
\text { факты. Давать } \\
\text { информацию, объ- } \\
\text { яснять, излагать }\end{array}$ & $\begin{array}{l}\text { Побуждение к удовлет- } \\
\text { ворению потребности } \\
\text { высказывания крими- } \\
\text { нальным способом }\end{array}$ & $\begin{array}{l}\text { Призывы к совершению } \\
\text { преступлений, выска- } \\
\text { зывания, касающиеся } \\
\text { оправдания террориз- } \\
\text { ма; интеллектуальное } \\
\text { пособничество советами, } \\
\text { указаниями, инструк- } \\
\text { циями; подстрекатель- } \\
\text { ство словом }\end{array}$ \\
\hline
\end{tabular}

\section{Список использованной литературы}

1. Шапиро С. А. Мотивация и стимулирование персонала / С. А. Шапиро. - М. : Гроссмедиа, 2005. - 224 с.

2. Вилюнас В. К. Психологические механизмы мотивации человека / В. К. Вилюнас. М. : Изд-во МГУ, 1990. - 288 с.

3. Ильин Е. П. Мотивация и мотивы / Е. П. Ильин. - Спб. : Питер, 2008. - 512 с.

4. Лунеев В. В. Преступное поведение: мотивация, прогнозирование, профилактика / В. В. Лунеев. - М. : Изд-во Воен. ун-та, 1980. - 137 с.

5. Кирсанова О. С. Психология криминальной мотивации женщин, осужденных к лишению свободы : дис. ... канд. психолог. наук : 19.00.06 / О. С. Кирсанова. — Рязань, 2011. -175 c.

6. Дьюсбери Д. Поведение животных: сравнительные аспекты / Д. Дьюсбери. - М. : Мир, 1981. - 480 с.

7. Кудрявцев В. Н. Причинность в криминологии (о структуре индивидуального преступного поведения) / В. Н. Кудрявцев. - М. : Проспект, 2007. — 176 с.

\section{Baikal Research Journal}


8. Скляров С. В. Вина и мотивы преступного поведения как основание дифференциации и индивидуализации уголовной ответственности : автореф. дис. ... д-ра юрид. наук : 12.00 .08 / С. В. Скляров. - М., 2004. - 45 с.

9. Бартол К. Психология криминального поведения / К. Бартол. - СПб. : ПраймЕврознак, 2004. - 352 с.

10. Кудрявцев В. Н. Борьба мотивов в преступном поведении / В. Н. Кудрявцев. M. : HOPMA, 2009. $-127 \mathrm{c}$.

11. Антонян Ю. М. Личность преступника. Криминолого-психологическое исследование / Ю. М. Антонян, В. Е. Эминов. - М. : Норма, 2010. - 368 с.

12. Шиханцев Г. Г. Юридическая психология / Г. Г. Шиханцев. - М. : Зерцало, 1998. - 341 c.

\section{References}

1. Shapiro S. A. Motivatsiya i stimulirovanie personala [Motivation and staff incentive]. Moscow, Grossmedia, 2005. 224 p.

2. Vilyunas V. K. Psikhologicheskie mekhanizmy motivatsii cheloveka [Psychological mechanisms of human motivation]. Moscow, Lomonosov Moscow State University Publ., 1990. 288 p.

3. Ilin E. P. Motivatsiya i motivy [Motivation and motives]. Saint Petersburg, Piter Publ., 2006. $512 \mathrm{p}$.

4. Luneev V. V. Prestupnoe povedenie: motivatsiya, prognozirovanie, profilaktika [Criminal behaviour: motivation, forecasting, prevention]. Moscow, Military University, 1980. $137 \mathrm{p}$.

5. Kirsanova O. S. Psikhologiya kriminal'noi motivatsii zhenshchin, osuzhdennykh $k$ lisheniyu svobody. Kand. Diss. [Psychology of criminal motivation of women sentenced to imprisonment. Cand. Diss.]. Ryazan, 2011. 175 p.

6. Dewsbury Donald A. Comparative Animal Behavior. New York, McGraw-Hill Book Company, 1978. 452 p. (Russ. ed.: Dewsbury Donald A. Povedenie zhivotnykh: sravnitel'nye aspekty. Moscow, Mir Publ., 1981. 480 p.).

7. Kudrjavcev V. N. Prichinnost' v kriminologii (o strukture individual'nogo prestupnogo povedenija). [Causality in criminology (On individual criminal behavior structure)]. Moscow, Prospekt Publ., 2007, 176 p.

8. Sklyarov S. V. Vina i motivy prestupnogo povedeniya kak osnovanie differentsiatsii $i$ individualizatsii ugolovnoi otvetstvennosti. Kand. Diss. [Guilt and motives of criminal behaviour as a basis of differentiation and individualization of criminal responsibility. Cand. Diss.]. Moscow, 2004. $45 \mathrm{p}$.

9. Bartol Curt R. Criminal behavior: a psychological approach. New York, Prentice Hall, 1986. 647 p. (Russ. ed.: Bartol Curt R. Psikhologiya kriminal'nogo povedeniya. Saint Petersburg, Praim-Evroznak Publ., 2004. 352 p.).

10. Kudryavtsev V. N. Bor'ba motivov v prestupnom povedenii [Conflict of motives in criminal behavior]. Moscow, Norma Publ., 2009. 127 p.

11. Antonyan Yu. M., Eminov V. E. Lichnost' prestupnika. Kriminologo-psikhologicheskoe issledovanie [Personality of the criminal. Criminological-psychological research]. Moscow, Norma Publ., 2010. 368 p.

12. Shikhantsev G. G. Yuridicheskaya psikhologiya [Juridical Psychology]. Moscow, Zertsalo Publ., 1998. 341 p.

\section{Информация об авторе}

Жлуров Длитрий Витальевич - кандидат юридических наук, доцент, кафедра уголовного права, криминологии и уголовного процесса, Байкальский государственный университет, 664003, г. Иркутск, ул. Ленина, 11, e-mail: zdevraz@yandex.ru.

\section{Author}

Dmitry V. Zhmurov - PhD in Law, Associate Professor, Chair of Criminal Law, Criminology and Criminal Procedure, Baikal State University, 11 Lenin St., 664003, Irkutsk, e-mail: zdevraz@yandex.ru.

\section{Baikal Research Journal}




\section{Для цитирования}

Жмуров Д. В. Криминальная мотивация / Д. В. Жћмуров // Baikal Research Journal. 2018. - T. 9, № 1. - DOI : 10.17150/2411-6262.2018.9(1).17.

\section{For Citation}

Zhmurov D. V. Criminal Motivation. Baikal Research Journal, 2018, vol. 9, no. 1. DOI: 10.17150/2411-6262.2018.9(1).17. (In Russian).

\section{Baikal Research Journal}

